\title{
Impact of corona virus on nature of work, income and time spent by women
}

\begin{abstract}
Corona virus emerged from Sea food market, China but it affected on all countries including women, men and children. Women are most affected economically, emotionally and work by Corona virus. Immediately after the outbreak of corona virus, Central and State governments introduced lockdown of economy. All women working in an informal sector lost their job and income. Those women working in formal sector had more online workload without time constraints. Household chores, child care, family members care, carry vegetables and grocery was routine activities for women. Such activities increased more work burden on women. Other member were expected to cooperate to women in work but they never cooperated to women. Over work and family related violence made women more worse in this pandemic.
\end{abstract}

Volume 10 Issue 3 - 202I

\author{
Sanjay Jayawant Rode \\ Somaiya Vidyavihar University, Department of Economics, India
}

Correspondence: Sanjay Jayawant Rode, Somaiya Vidyavihar University, Department of Economics, India, Tel 9967575703, ORCID 0000-0003-4506-895X, Email Sanjay.rode@somaiya.edu

Received: May 23, 2021 | Published: June 22, 2021

\section{Introduction}

Corona virus emerged from bats in Wuhan seafood market, China. It is a deadly virus and negligence of health may cause death. Due to its mutations, people fear for their life. Corona virus has affected equally on male, and female in all countries. In order to reduce the spread of virus and infections, central and state Governments introduced lock down. During lockdown, except essential services everything is forced to close down and people forced to stay home After announcement of lockdown in India during March 2020, women were faced with a number of social, economic, domestic and violence issues. The current COVID-19 crisis presents novel characteristics that have affected economic, health and social phenomena over wide swaths of the economy. Social distancing measures to combat the spread of the virus, such as working from home and school closures, have placed an additional tremendous burden on families. ${ }^{1}$ Immediately after lockdown, many women lost their jobs. Women working in informal sector such as cooking, cleaning, washing clothes, domestic help, child care, attendant, construction, vegetable vendor etc. lost job for an indefinite period. Their income were irregular and low. In lockdown, it was not possible to do such work. Their income declined significantly. The families suffered a lot due to loss of employment and income. Women with formal sector jobs performed online tasks. But those engaged in private sector, faced number of problems. The office work had no time limits. They worked late night on assigned tasks. Continuous work assessment and targets, forced women to sit long time in front of screen. Office work and household work mixed with each other. They found office hours before lockdown was much better than online work.

There is unequal involvement in household chores by women and men as it is higher in women that in men, and the perception of partner involvement is lower in women that in men. ${ }^{2}$ Women in general wake up early in the morning. They clean the house, prepare breakfast for all family members. Most of the day, they spend time in the kitchen. Every member requires personal care and service. They prepare lunch for all members and wash utensils at home. Domestic maids are not available because of the lockdown. Those women have big families, house work is more. Getting Help in domestic work is not possible. They hardly get time for themselves and personal care. They hardly get time to read newspaper, watch television or talk on phone with relatives. For the last one year, they have not visited their mother's house, visit the garden, watched cinema or went to see drama. Due to lockdown, all members are present at home and they require care. The hotels and restaurant are closed due to lockdown. Women have no choice but to continue cooking and doing other work for family. It is daily routine activity for every woman. Children are at home since last year. Their school work is online. In cities, there is not much space available for every member of family. Online meetings of husband and wife, online school for children are daily schedule in almost all houses in cities. At initial stage, online work and schooling is enjoyed by all. But after one year, many lost interest in online activities. Children attended online school but examination was not possible due to corona virus. Therefore they lost interest in study. They started watching number of programs on internet. Few played different games on mobile. All members of family are busy on screen. Everybody lost interest in exercise, and yoga. Women are struggling to control the screen time of the children. But children have no choice because gardens, public spaces are closed due to lockdown and they cannot go outside home. It is the cause of quarrels and tensions in many families. Online work, managing children and household chores is difficult task for most of the women. For all women, completing household chores, bringing vegetables, and grocessary glossary is a routine activity. During lockdown, shops were opened for few hours in a day. There was too much crowd at shops. Bags masks, money, social distancing, transport were the issues faced by women. Corona virus is life and death issue for women but they work for family members continuously without break.

After outbreak of corona virus, involvement of women in various community work has declined very sharply. Earlier, women were meeting with their friends to talk about daily activities, participating in festivals, expressing a different types of need and learning from each other. Every day was a learning experience. Children accompanied them. But after corona virus, they never went out of their house. They never met their loved once. They are thinking that they have lost their own world in corona virus. Corona virus has affected every family member. They are aware of cough, cold, fever of members of their family. Role of women is very important in medical treatment. They are taking care of every member with boiling water, providing medical care, noting down of body temperature, level of oxygen with oximeter. The list of work for members is never ending task. It is 
the responsibility of the women to provide vaccine to older people in house. She is reading information about vaccination. Booking the slots for vaccination, and taking the older to vaccination center. Women are adjusting time as per the need of the family.

Most of the women do not have time for personnel things. They have not gone out of kitchen for many days. They take care of whole family on 24 hour basis. Before corona virus women were relaxing in the at afternoons. The husbands go to work and children go to school. But now all are at home and demanding a number of things continuously. The responsibilities of the women have increased. They need to cook food for family, start the online class of children, help them in their online class activities, monitor children during school hours, take pictures of school activities and send homework to teacher and help children in doing the homework. There is division of work in house but women do more work in comparison to the male members. They get tired of doing all domestic chores. They do not have single minute to relax. Body shows reaction of overwork but they have no choice but to continue work. Many people lost their job during corona virus outbreak. Women have saved some money. During financial emergency, they have given their money. Many gave their valuable gold to members of their family. Many women lost money and valuable ornaments in this pandemic. It will take many years to overcome the financial loss. Few women took loan from relatives and friends to help their family. How women will repay such loan after death of their husband?

Due to corona virus, many families have either lost job, business and income. Situation outside home is very critical. Family members have tension of regular income and business activities. Most of the time, members do not do anything but listen to the news. They often quarrels on small issues such as say something to wife's relatives, special food items, cooked vegetables and taste of food, child care, illness of members etc. Fresh vegetables are not available in market due to lockdown and they sold at very high price. Women are struggling for family. But uncooperative husband and in laws put blame on her and few husband beat wife too. Males do not coordinate and work in house. Women do not complaint to police or say something about members and husband. They often cry in kitchen but family members often ignore it. Emotional support has not received by family members to women during corona virus period.

Continuous work without respect, responsibilities, self care, women are helpless and are in depression. They take few medicines and start work again. During sickness, they cannot order food from hotel and restaurant. There is no stop for their domestic work. Many women lost their loved ones in the pandemic such as husband, mother, father or in laws. They often get emotional; cry some time and again start work. They will continue work but how long? It is unanswered question.

\section{Conclusion}

In today's modern era women is working to provide financial support to her male counterpart. In spite of her positive contribution to the family her image of woman being a home-maker is not much changed. Even if she works, she is expected to cook food, take care of kids and all other household duties. This busy schedule deprives her of peace, rest, sleep, independent thinking and luxury life. It so happens sometimes the children are neglected for which she the only person blamed. ${ }^{3}$ Due to corona virus, women are blamed for all kind of work and issues. Every member of family must understand each other's role and responsibilities and share all kinds of work within and outside house. Work characteristics play a fundamental role in the difference in work-family conflict (WFC) between not only occupational but also gender differences. Stressful work characteristics among professional and technical workers and among women in all work roles should be addressed to reduce occupational and gender differences in WFC. ${ }^{4}$ Every family must treat women with respect and appreciate her hard work. Children must be taught responsibilities and work sharing practices. Families must come ahead with good work sharing practices among male and female. It will certainly help to solve work burden on women in society and gender balance in work would be achieved automatically.

\section{Acknowledgments}

None.

\section{Funding}

None.

\section{Conflicts of interest}

None.

\section{References}

1. Oggero N, Paola P, Daniela DB, Mariacristina R. Women's and men's work, housework and childcare, before and during COVID-19. Review of Economics of the Household. 2020;18:1001-1017.

2. Javier C, Eva C. Gender Inequality in Household Chores and WorkFamily Conflict. Front Psychol. 20189;9:1330.

3. Gouri Prabha PV. Challenges And Problems Of A Working Woman. International Journal of Innovative Research and Advanced Studies. 2019;6(5):118-129.

4. Koura U, Sekine M, Yamada M, et al. Work, family, and personal characteristics explain occupational and gender differences in work-family conflict among Japanese civil servants. Public Health. 2017;153:78-90. 